\title{
Use of individual race results in the estimation of genetic parameters of trotting performance for Finnhorse and Standardbred trotters
}

\author{
Terhi Thuneberg-Selonen \\ Agricultural Research Centre of Finland, Animal Production Research, FIN-31600 Jokioinen, \\ Finland, e-mail: terhi.thuneberg-selonen@mtt.fi
}

Jukka Pösö

Agricultural Research Centre of Finland, Animal Production Research, FIN-31600 Jokioinen, Finland.

Current address: Finnish Animal Breeding Association FABA, PO Box 40, FIN-01301 Vantaa, Finland

Esa Mäntysaari

Agricultural Research Centre of Finland, Animal Production Research, FIN-31600 Jokioinen, Finland

Matti Ojala

Department of Animal Science, PO Box 28, FIN-00014 University of Helsinki, Finland

The heritability and repeatability for trotting performance traits were estimated from individual race results. Data comprised of records from 1991 to 1995 for 4808 Finnhorses and from 1993 to 1995 for 5869 Standardbred trotters. The statistical model included the additive genetic effect of an animal and two permanent environmental effects, and the fixed effects of sex, age, starting method*starting lane combination, driver and race. The first permanent environmental effect described repeatability over a horse's career while the second one characterized repeatability within a racing year. Variance components for three trotting performance traits were estimated by the animal model and the method of restricted maximum likelihood (REML). Heritability and repeatability estimates were moderately high for time at finish $\left(\mathrm{h}^{2}=0.23-0.28\right.$ and $\left.\mathrm{r}=0.50-0.57\right)$, moderate for ranking within a race $\left(\mathrm{h}^{2}=0.12\right.$ and $\mathrm{r}=0.25)$ and low for earnings $\left(\mathrm{h}^{2}=0.05-0.09\right.$ and $\left.\mathrm{r}=0.15-0.18\right)$. Time at finish seemed to be the most usable measure of trotting performance because of its wide information substance. However, time at finish does not take into account records of disqualified horses or of those which did not finish, but use of earnings, either from individual race results or preferably from annual records, is one possible way to consider records of such horses.

Key words: animal model, best linear unbiased prediction, heritability, racing performance, repeatability, trotting horses 


\section{AGRICULTURAL AND FOOD SCIENCE IN FINLAND}

\section{Thuneberg-Selonen, T. et al. Estimation of genetic parameters of trotting performance}

\section{Introduction}

The Finnish Trotting and Horse Breeding Association (Suomen Hippos r.y.) is planning to change the breeding value estimation for trotting horses from a selection index method to the BLUP (Best Linear Unbiased Prediction) -methodology. Presently, breeding value estimation of trotters in Finland is based on annually summarized race records and the selection index method which does not completely take into account information on relatives. Therefore, indices based on performance of an individual and its progeny are calculated separately. Use of animal model BLUP, which has become a standard method for genetic evaluation of all major domestic animal species, allows all known relationships to be potentially accounted for, such that environmental effects and breeding values for animals can be estimated simultaneously.

In many countries the breeding value estimation of trotters is based on annually summarized race records either from individual age classes or pooled career records. Traits, such as best annual racing time, earnings, number of first placings, number of first to third placings and number of disqualified races are utilized to indirectly describe the performance of a horse for each considered year. The most common factors affecting annual records are sex, age, racing or birth year and country of birth (e.g. Ojala and Hellman 1987, Katona and Distl 1989, Minkema 1989). Several other factors that have an effect on individual race events, such as driver or starting lane are assumed to level out.

The main disadvantage of using annual records is that all available information, e.g. level of a race, trainer, driver or race track, can not be utilized since they may change from race to race. Such effects may level out when breeding value estimation of sires with a large number of offspring is considered. However, for individual horses with a limited number of races and with few or no offspring they can have a substantial impact. In a few studies individual race records have been used as a basis of breeding value esti- mation and the factors affecting single race events have been taken into account. Nevertheless, comparison of horses in these studies has still been conducted indirectly. In German data (Distl et al. 1982) each single racing time was pre-adjusted for the effects of race track, track condition, starting method and distance; the averages of adjusted racing times were subsequently used in the final analyses of separate age classes. Leroy et al. (1989) analysed the best life time of Belgian trotters by animal model from records corrected for the effects of sex, age, race track, date of birth, date of record, type of start and distance.

Yet another possible approach would be to employ individual race results and to compare horses directly within the same race, as happens in practice, by subsuming into the statistical model a factor common to all horses in the race. This would make better use of all the information available: level of the race, driver, trainer, starting method and lane, resulting in a more accurate statistical model. Use of individual race results would allow breeding value estimation in a natural manner that is feasible whenever needed. Moreover, operating with individual results and comparing horses directly against each other may also reduce the number of traits required for evaluation.

The purpose of this study was to define a statistical model and quantify genetic and non-genetic variation in trotting performance traits utilizing individual race results and the animal model. Our aim was also to gain experience on the traits derived from individual race results; the importance of the different traits is discussed.

\section{Material and methods}

In Finland, individual race results have been recorded by The Finnish Trotting and Horse Breeding Association since 1984. Data was extracted from the database, which contains individual race results of 14000 Finnhorses and 21000 
Vol. 8 (1999): 353-363.

Table 1. Number of horses raced in each age class.

\begin{tabular}{|c|c|c|c|c|c|c|c|c|}
\hline \multirow{2}{*}{$\begin{array}{l}\text { Age- } \\
\text { class }\end{array}$} & & \multicolumn{3}{|c|}{ Finnhorse } & & \multicolumn{3}{|c|}{ Standardbred trotter } \\
\hline & & Males & Females & Total & & Males & Females & Total \\
\hline 1 & 4-year-olds & 628 & 392 & 1020 & 3 -year-olds & 756 & 695 & 1451 \\
\hline 2 & 5 -year-olds & 1067 & 728 & 1795 & 4-year-olds & 1231 & 1215 & 2446 \\
\hline 3 & 6-year-olds & 1150 & 769 & 1919 & 5-year-olds & 1201 & 1171 & 2372 \\
\hline 4 & 7-year-olds & 1145 & 695 & 1840 & 6-year-olds & 930 & 812 & 1742 \\
\hline 5 & $\geq 8$ year-olds & 1470 & 843 & 2313 & $\geq 7$ year-olds & 878 & 716 & 1594 \\
\hline
\end{tabular}

Table 2. Average number of observations per horse in two data sets. Number of horses raced in each year is given in parenthesis.

\begin{tabular}{ccccccc}
\hline & \multicolumn{3}{c}{ Finnhorse } & \multicolumn{3}{c}{ Standardbred trotter } \\
& Males & Females & Total & Males & Females & Total \\
\hline 1991 & $7.8(1539)$ & $6.8(836)$ & $7.4(2375)$ & & & \\
1992 & $8.2(1453)$ & $7.0(800)$ & $7.7(2253)$ & & & \\
1993 & $8.1(1379)$ & $7.3(824)$ & $7.8(2203)$ & $8.5(1783)$ & $7.9(1592)$ & $8.2(3375)$ \\
1994 & $7.7(1291)$ & $7.0(754)$ & $7.4(2045)$ & $8.2(1736)$ & $7.5(1563)$ & $7.9(3299)$ \\
1995 & $7.3(1247)$ & $6.4(794)$ & $7.0(2041)$ & $7.1(1892)$ & $6.7(1693)$ & $6.9(3585)$ \\
\hline
\end{tabular}

Table 3. Structure of pedigree information.

\begin{tabular}{|c|c|c|c|c|c|c|c|c|}
\hline \multirow{3}{*}{$\begin{array}{l}\begin{array}{l}\text { Number of } \\
\text { progeny }\end{array} \\
1\end{array}$} & \multicolumn{4}{|c|}{ Finnhorse } & \multicolumn{4}{|c|}{ Standardbred trotter } \\
\hline & \multicolumn{2}{|c|}{ Sires } & \multicolumn{2}{|c|}{ Dams } & \multicolumn{2}{|c|}{ Sires } & \multicolumn{2}{|c|}{ Dams } \\
\hline & 172 & $(40 \%)$ & 1810 & $(61 \%)$ & 208 & $(38 \%)$ & 2319 & $(63 \%)$ \\
\hline $2-5$ & 131 & $(30 \%)$ & 1139 & $(38 \%)$ & 157 & $(29 \%)$ & 1316 & $(36 \%)$ \\
\hline $6-15$ & 63 & $(14 \%)$ & 17 & $(1 \%)$ & 90 & $(16 \%)$ & 21 & $(1 \%)$ \\
\hline $16-50$ & 43 & $(10 \%)$ & & & 67 & $(12 \%)$ & & \\
\hline $51-100$ & 16 & $(4 \%)$ & & & 14 & $(3 \%)$ & & \\
\hline $101-$ & 8 & $(2 \%)$ & & & 11 & $(2 \%)$ & & \\
\hline Total & 433 & & 2966 & & 547 & & 3656 & \\
\hline
\end{tabular}

Standardbred trotters with large pedigrees and will be used in prospective BLUP-evaluations. For variance component estimation different data sets were utilized for two breeds: between 19911995 for Finnhorses and 1993-1995 for Standardbred trotters. Due to computational limitations, data sets included race results from nine major race tracks in southern Finland. Race records from minor tracks were excluded. Also, races in which the number of trotters was less than six were deleted to ensure big enough comparison groups. This resulted in 81643 individual race results of 4808 Finnhorse trotters (2899 males and 1909 females) and 78455 individual race results of 5869 Standardbred trotters (3003 males and 2866 females). Characteristics of the data are presented in Tables 1 and 2. Finnhorse trotters had 433 sires with an average of 11.1 offspring and 2966 dams with an average of 1.6 offspring. The number of Standardbred sires was 547 , having on average 10.7 offspring and the number of dams was 3656 with an average of 1.6 offspring. Distribution of the number of offspring is presented in Table 3. When known, pedigree information from minimum of three generations (the animal, its parents and grand- 


\section{Thuneberg-Selonen, T. et al. Estimation of genetic parameters of trotting performance}

Table 4. Classification of driver, driver distribution and driver solutions from the mixed model equations for time at finish in Finnhorse and Standardbred trotter data.

\begin{tabular}{llcccc}
\hline & & \multicolumn{2}{c}{ Finnhorse data } & \multicolumn{2}{c}{ Standardbred trotter data } \\
Class & Starts/driver & Number of drivers & Solution & Number of drivers & Solution \\
\hline 1 & $\leq 5$ & $655(31 \%)$ & 0 & $678(37 \%)$ & 0 \\
2 & $6-15$ & $406(19 \%)$ & -1.84 & $408(22 \%)$ & -0.71 \\
3 & $16-30$ & $335(16 \%)$ & -2.36 & $249(13 \%)$ & -1.02 \\
4 & $31-50$ & $251(12 \%)$ & -2.64 & $153(8 \%)$ & -1.39 \\
5 & $51-100$ & $237(11 \%)$ & -2.95 & $168(9 \%)$ & -1.45 \\
6 & $101-500$ & $203(9 \%)$ & -3.46 & $162(9 \%)$ & -1.80 \\
7 & $\geq 500$ & $46(2 \%)$ & -3.85 & $43(2 \%)$ & -2.25 \\
\hline Total & 2133 & & 1861 & \\
\hline
\end{tabular}

parents) was used in the construction of the additive relationship matrix. The pedigree files consisted of 4674 Finnhorse trotters and 6930 Standardbred trotters which did not have a race result of their own in the data set.

To rank horses, individual race results can be used in at least three different ways. Candidate traits analysed were total time at finish, earnings (processed as a fourth root transformation of earnings) and ranking within a race. Horses that did not finish (DNF) or that were disqualified had an observation for earnings, but not for time at finish nor ranking.

The following univariate model for each trait was assumed:

$\begin{aligned} \mathrm{y}_{\mathrm{ijklmnop}}= & \operatorname{sex}_{\mathrm{i}}+\operatorname{age}_{\mathrm{j}}+\operatorname{lane}_{\mathrm{k}}+\mathrm{dri}_{1}+\operatorname{race}_{\mathrm{m}}+\mathrm{a}_{\mathrm{n}}+ \\ & \operatorname{pe}_{\mathrm{n}}+\mathrm{pe}_{\mathrm{no}}+\mathrm{e}_{\mathrm{ijklmnop}}\end{aligned}$

where $\mathrm{y}_{\mathrm{ijklmnop}}$ is trotting performance trait (time at finish (s), earnings or ranking within a race); $\operatorname{sex}_{\mathrm{i}}$ is the fixed effect of sex, $\mathrm{i}=1-2$; age $_{\mathrm{j}}$ is the fixed effect of age class, $j=1-5$; lane $_{k}$ is the fixed effect of starting method*starting lane-subclass, $k=1-61$ for Finnhorse and $k=1-51$ for Standardbred trotter; dri ${ }_{1}$ is the fixed effect of driver class, $1=1-7$; race $_{\mathrm{m}}$ is the fixed effect of race, $m=1-6516$ for Finnhorse and $m=1-6453$ for Standardbred trotter; $a_{n}$ is the random additive genetic effect of an animal, normally and independently distributed (NID) $\left(0, \sigma_{a}^{2}\right)$; pe $1_{n}$ is the random effect of permanent environment of an animal over the whole racing career, $\operatorname{NID}\left(0, \sigma_{p e l}^{2}\right)$; pe $2_{\text {no }}$ is the random effect of permanent environment of an animal within a year, NID $\left(0, \sigma_{p e 2}^{2}\right)$, and $\mathrm{e}_{\mathrm{ijklmnop}}$ is random residual error, $\operatorname{NID}\left(0, \sigma_{e}^{2}\right)$.

The age effect was classified into one-yearperiods so that 4-, 5-, 6-, 7- and $\geq 8$-year-old Finnhorses and 3-, 4-, 5-, 6- and $\geq 7$-year-old Standardbred trotters established five classes within two breeds. Results of the horses from the youngest age classes (three-year-old Finnhorses and two-year-old Standardbred trotters) were excluded from the variance component estimation due to the scarcity of such observations. Starting method*starting lane effect was a combination of two starting methods (auto versus volt start) each with the starting lanes. Auto start destines a start behind a car (flying start) and volt start is known as handicap race. Starting lanes in the two starting methods differ according to trotting race regulations; therefore, starting method and lane had to be taken into account together. We renumbered starting lanes so that lanes from 1 to 12 of each volting group had the following codes: lanes in the first volting group coded 1-12, lanes in the second volting group coded 21-32, lanes in the third volting group coded 41-52, and so on. The auto start included only lanes $1-12$. For Finnhorses, $35 \%$ of the races were auto and $65 \%$ volt starts. Corresponding values for Standardbred trotters were $52 \%$ and $48 \%$, respectively. The driver effect was divided into seven classes according to the number of starts of each driver (Table 4). The race effect was a com- 
Vol. 8 (1999): 353-363.

bination of race track, date of race and race number.

Variance components were estimated with animal model and restricted maximum likelihood (REML) method using the AI (average information) algorithm (Johnson and Thompson 1995). Analyses were conducted within the DMU package (Jensen and Madsen 1994).

\section{Results and discussion}

\section{Fixed effect solutions}

Male horses were superior to females, but the magnitude of difference in time at finish between the sexes was larger for the Finnhorse $(1.0 \mathrm{~s})$ than for the Standardbred trotter $(0.5 \mathrm{~s})$. However, based on earnings and ranking within a race, differences between sexes were greater for Standardbred trotters. For time at finish, older Finnhorses were faster than the younger ones with diminishing superiority by age. Similar results of sex and age effects have been reported in several studies (Rönningen 1975, Katona and Osterkorn 1977, Ojala 1982, Physick-Sheard 1986, Ojala and Hellman 1987). In contrast, for Standardbred trotters the 4-year-olds were the best, while the oldest horses ( $\geq 7$-year-olds) had the slowest times. For each breed, both in terms of earnings and ranking within a race, the youngest age classes were more successful than older ones (Fig. 1). For earnings, one reason for the superiority of the youngest horses could be differences in prize level, since young trotters compete in races with the biggest prizes. Ranking within a race should behave as time at finish, and therefore the superiority of the young horses is difficult to reconcile. However, the small size of data sets did affect the results; when observing fixed effect solutions from larger data sets used for breeding value estimation, the solutions were slightly different though the general tendency remained the same.
In both breeds, the starting method*starting lane subclass affected these three traits in a similar manner. The effect of the starting lane for the time at finish in auto and volt start for Finnhorse trotters is presented in Fig. 2. For the auto start, the difference between the best and worst lanes was $0.5 \mathrm{~s}$ while for the volt start, the difference between the best and worst lanes was $1.7 \mathrm{~s}$ (in first volting group). In the two starting methods it can be seen that horses which started on inside lanes performed better than those starting on outside lanes. Generally, for the volt start horses in the sixth and seventh lanes are assumed to have an advantage, because as a result of trotting regulations they have a special position in volting system and can therefore carry more speed at the start line. Our study does not support this argument (see Fig. 2.). This can be caused by the fact that not all drivers nor horses are able to exploit this opportunity at the start of a race.

In the two breeds, the effect of a driver was significant: increased driving experience, assessed as an increase in the number of starts per driver, was associated with greater racing success (Table 4). Logically the effects of trainer and driver are random, and a statistical model in which the driver effect was assumed random was also tested. However, this approach inflated the variance parameter estimates due to the confounding effects of driver, additive genetic and permanent environment, since the best horses are more likely to be assigned to professional drivers and trainers. Furthermore, several horses are driven only by one driver, and therefore the effects of driver and permanent environment are difficult to distinguish. Consequently, in the final model the effect of a driver was described through a classified fixed factor based on driver experience. Information of the trainer was not available in the database, and therefore could not be included in the model. As a result, the effects of trainer and management have probably to some extent influenced the variance components for breeding value and permanent environment. 
Thuneberg-Selonen, T. et al. Estimation of genetic parameters of trotting performance
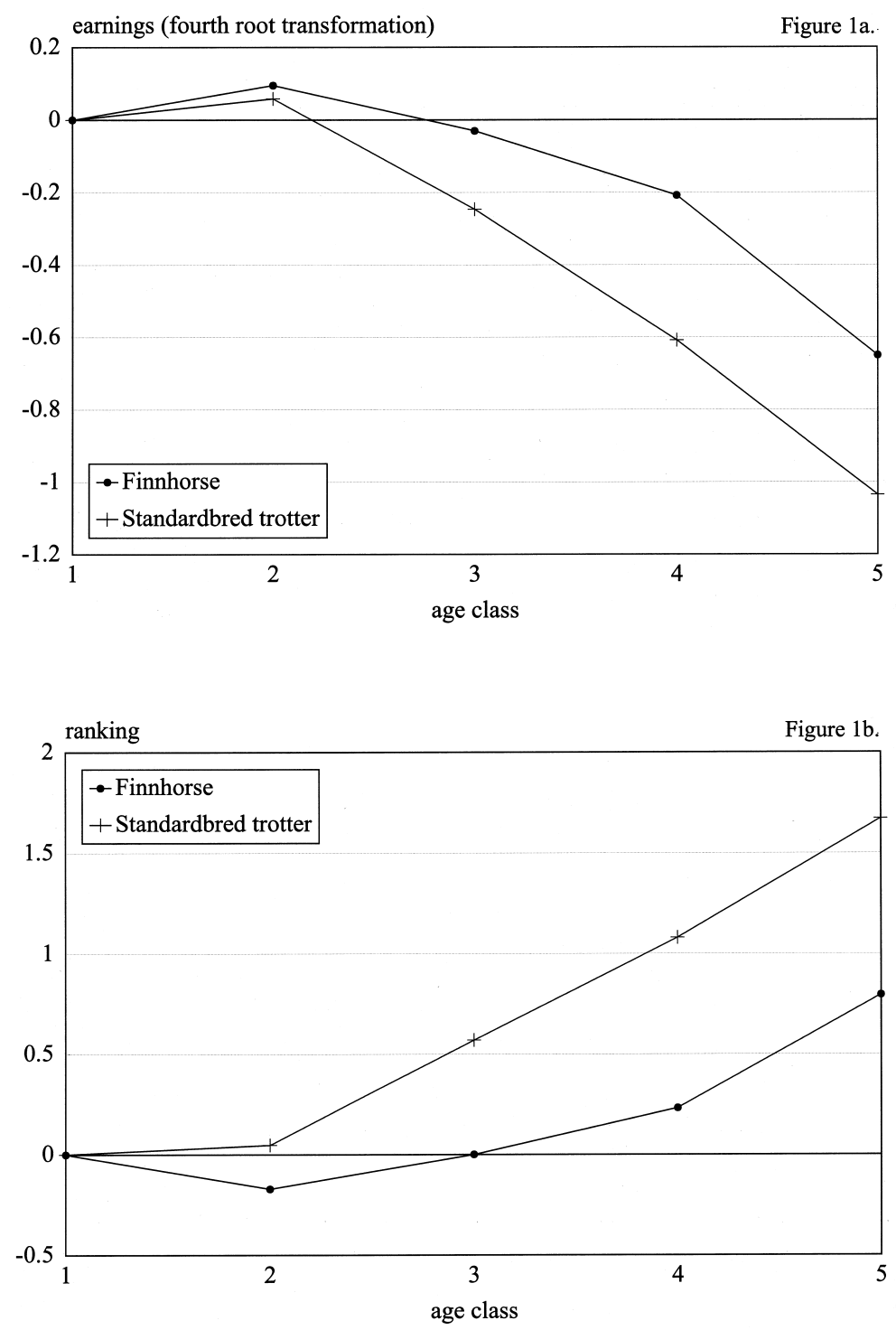

Fig. 1. The effect of age on earnings (1a) and ranking within a race (1b).

\section{Heritabilities and repeatabilities}

Heritability and repeatability estimates for the three traits were of same magnitude for the two breeds, indicating a moderately high genetic variation for the time at finish and low genetic variation for earnings and ranking within a race (Table 5). Higher heritability estimates for the time at finish is likely to reflect the amount of information for a trait. Time at finish is a comprehensive measure of racing success. Even though racing time is of no importance itself, it contains information on both the order between horses and distances between them within a race, while ranking within a race provides only information of the order in ordinal scale. Earnings is likely to be the least complete measure of trotting performance, since it wastes information due 
Vol. 8 (1999): 353-363.

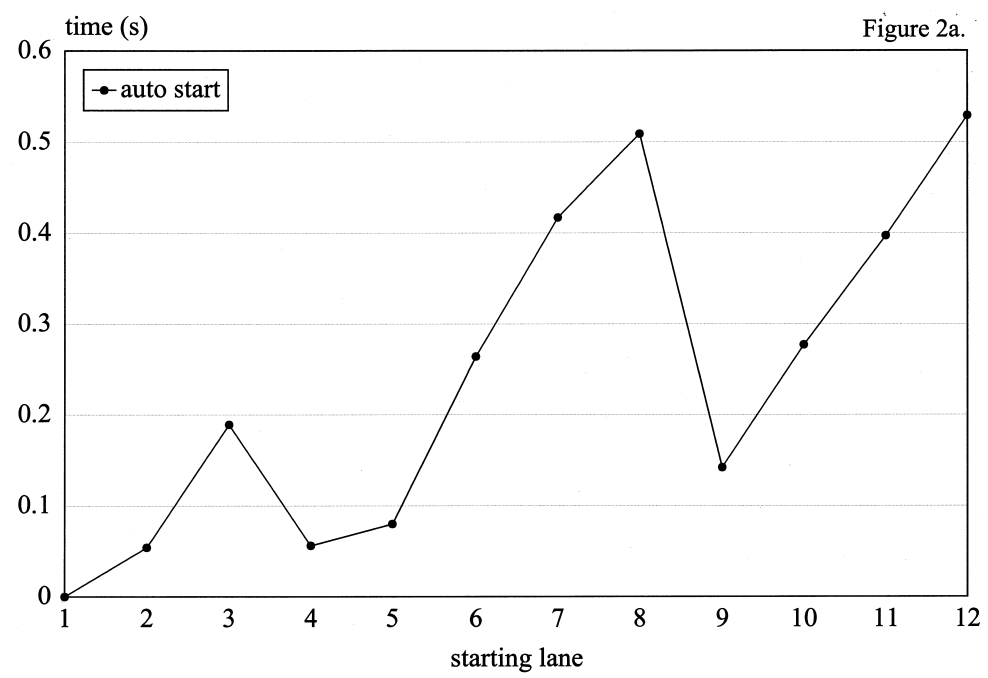

Fig. 2. The effect of starting method*starting lane on time at finish in auto (2a) and volt starts (2b) for the Finnhorse.

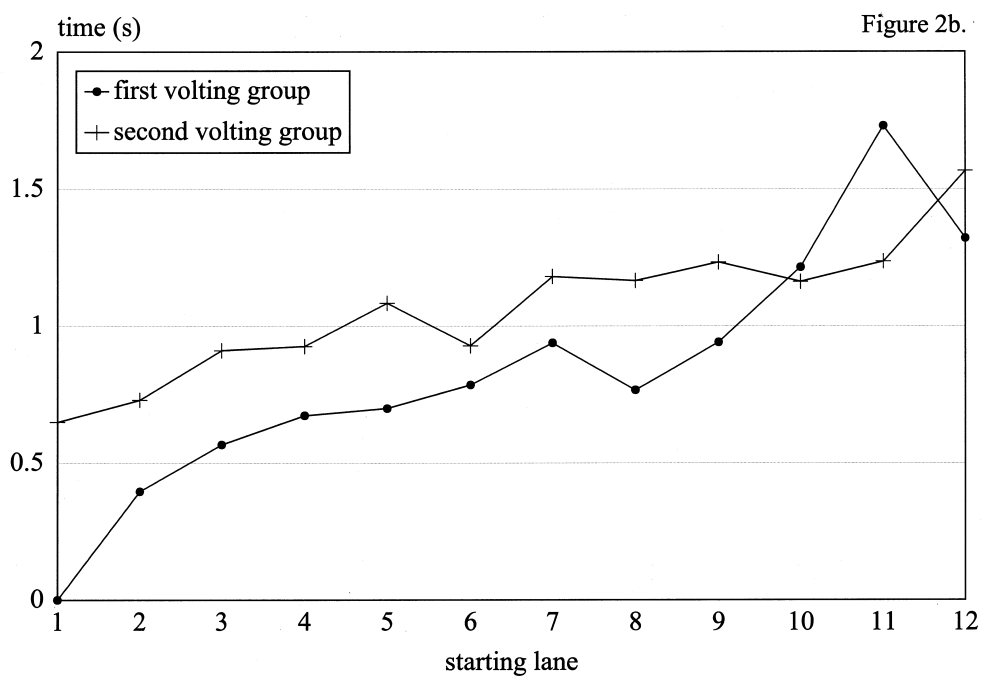

to setting all the horses with zero earnings in a race equal. On the other hand, it indirectly carries information about the records of DNF and disqualified horses. However, annually summarized earnings might be more appropriate, because it follows better normal distribution (after transformation) and makes possible to integrate the results from abroad which is not possible when utilizing individual race results.
The repeated records of a horse are mutually correlated within the career of a horse. However, time interval between the first and last race of a horses's career can be long, and therefore associations between records at the beginning and end of a career are likely to be weaker than associations within a racing year. Therefore, a second permanent environmental effect was fitted to the model to describe the covariance struc- 


\section{Thuneberg-Selonen, T. et al. Estimation of genetic parameters of trotting performance}

Table 5. Estimates of variance components, heritabilities $\left(\mathrm{h}^{2}\right)$ and repeatabilities for time at finish, earnings and ranking within a race.

\begin{tabular}{llccccccc}
\hline & & \multicolumn{3}{c}{ Variance components } & \multicolumn{3}{c}{ Genetic parameters } \\
& Trait & animal & pe1 & pe2 & residual & $\mathrm{h}^{2}$ & $\mathrm{r}$ & $\mathrm{r} 2$ \\
\hline \multirow{3}{*}{ Finnhorse } & Time at finish & 5.88 & 8.48 & 3.58 & 7.46 & 0.23 & 0.57 & 0.71 \\
& Earnings & 0.42 & 0.77 & 0.60 & 5.97 & 0.05 & 0.15 & 0.23 \\
& Ranking & 1.42 & 1.60 & 1.24 & 7.64 & 0.12 & 0.25 & 0.36 \\
\hline \multirow{3}{*}{ Standardbred trotter } & Time at finish & 2.05 & 1.69 & 0.63 & 3.08 & 0.28 & 0.50 & 0.59 \\
& Earnings & 0.65 & 0.71 & 0.37 & 5.86 & 0.09 & 0.18 & 0.23 \\
& Ranking & 1.41 & 1.56 & 0.72 & 8.25 & 0.12 & 0.25 & 0.31 \\
\hline
\end{tabular}

pe1 = permanent environmental effect over whole racing career

pe 2 = permanent environmental effect within a year

r1 = repeatability over whole racing career

r2 = repeatability within a year

Table 6. Estimates of variance components for time at finish. In model 1, the non-genetic animal effect is modelled by within racing year and across racing years permanent environment. For model 2 the permanent environmental effect within racing year is excluded.

\begin{tabular}{|c|c|c|c|c|}
\hline & & & & \\
\hline & Additive & pe1 & pe2 & Residual \\
\hline Finnhorse & & & & \\
\hline model 1 & $5.88(23 \%)$ & $8.48(33 \%)$ & $3.58(14 \%)$ & $7.46(29 \%)$ \\
\hline model 2 & $5.00(21 \%)$ & $9.70(41 \%)$ & & $8.85(38 \%)$ \\
\hline Standardbre & & & & \\
\hline model 1 & $2.05(28 \%)$ & $1.69(23 \%)$ & $0.63(8 \%)$ & $3.08(41 \%)$ \\
\hline model 2 & $1.93(27 \%)$ & $2.03(28 \%)$ & & $3.31(46 \%)$ \\
\hline
\end{tabular}

pe1 = permanent environmental effect over whole racing career

pe $2=$ permanent environmental effect within a year

ture between records within a year. As expected, estimates of repeatability within a year were distinctly higher than repeatability over the entire career. To validate the assumption of two separate permanent environmental effects a simplified model was fitted without the within racing year animal effect pe2 (Table 6). Two permanent environmental effects accounted for more variation than only one permanent environmental effect, resulting in a smaller residual variance. The influence was more obvious with Finnhorse data which is probably due to evaluation of data collected over a longer period of time and the longer racing career of Finnhorse trot- ters. Pösö (1993) reported an average racing career length of 3.5 years for Finnhorses and 2.6 years for Standardbred trotters.

In earlier studies concerning individual race records, trait definitions and statistical models have differed from those in this study. Katona and Osterkorn (1977) ascertained that racing time is influenced by race track, track condition and starting method, and reported a heritability of adjusted racing time for 2-10 year-old horses of 0.20, while Katona and Distl (1989) found a heritability estimate for average racing time of 0.35. For Finnhorse trotters, Ojala and Van Vleck (1981) calculated repeatabilities at specific ages 
Vol. 8 (1999): 353-363.

from single records of a horse. Repeatability estimates varied for time at finish from 0.61 to 0.74 , for prize money $0.18-0.28$ and for rank at finish 0.14-0.42. Klemetsdal (1989) utilized precorrected results from single races; his heritability estimates for average racing time were similar in magnitude to time at finish in this study, varying from 0.17 to 0.19 for the Norwegian trotter (a so-called cold-blooded breed type as is the Finnhorse). However, heritability estimates for Standardbred trotters were close to zero $(0.01-$ 0.04). Compared to summarized records, our heritability estimates were somewhat lower than those reported for best racing time and earnings calculated from repeated annual records (Tavernier 1989, Pösö and Ojala 1997). Part of this difference comes from the statistical nature of the traits defined. The best annual time and the annual earnings clearly summarise the information of the individual race records, and are therefore expected to have higher heritabilities than the original observations. The best racing time is equal to the individual race record if the horse has only raced once, but will diverge to a biologically different trait when more records in a year are accumulated. Also, one must bear in mind that when analyzing total time at finish and having a fixed race effect in the model, in fact, observations become deviations from the winning time. This results in the trait resembling a general ranking than a time based trait.

One problem with the analysis of individual race records is that of results of horses that are either disqualified or do not finish. The propor- tion of the results of such horses was $15 \%$ and $10 \%$ in Finnhorse and Standardbred trotter data, respectively. Disqualifications and not finishing a race may be caused by conformation faults or a horse's character and temperament. Neglecting these records may lead to an overestimation of breeding values for those horses that are often disqualified but that do well when they finish a race. Therefore, when analysing time at finish and ranking within a race, we tested an approach where missing observations were replaced by pseudo records created by adding one second to the time of the last horse and one rank to the last placing in corresponding race. However, because the majority of disqualified and DNF observations occurred in the first volting group, this resulted in a situation where starting lane solutions in later volting groups became better than those in the first volting group. A more appropriate way to deal with this kind of selection bias would be the use of both time at finish and earnings in breeding value estimation, or to develop a multitrait evaluation where the time at finish is evaluated simultaneously with DNF status.

Acknowledgements. The current project was funded by the Finnish Trotting and Breeding Association (Suomen Hippos r.y.), Ministry of Agriculture and Forestry, and Agricultural Research Centre of Finland (MTT). The authors would like to express their gratitude to Terttu Peltonen and Jouko Hakala from the Finnish Trotting and Breeding Association for providing the data and for their patient cooperation.

\section{References}

Distl, O., Katona, Ö. \& Kräusslich, H. 1982. Vergleich der Zuchtwertschätzmethoden BLUP und CC beim Traber. Züchtungskunde 54: 157-164.

Jensen, J. \& Madsen, P. 1994. A user's quide to DMU, a package for analyzing multivariate mixed models. National Institute of Animal Science, Tjele, Denmark. Mimeo. 19p.

Johnson, D.L. \& Thompson, R. 1995. Restricted Maximum Likelihood estimation of variance components for univariate animal models using sparse matrix techniques and average information. Journal of Dairy Science 78: 449-456.

Katona, Ö. \& Distl, O. 1989. Sire evaluation in the German trotter (Standardbred) population. In: Langlois, B. (ed.). State of breeding evaluation in trotters. EAAP Publications No 42, Wageningen Pers, Wageningen. p. 55-61.

- \& Osterkorn, K. 1977. Genetisch-statistische Auswer- 


\title{
AGRICULTURAL AND FOOD SCIENCE IN FINLAND
}

\section{Thuneberg-Selonen, T. et al. Estimation of genetic parameters of trotting performance}

tung des Leistungsmerkmals Rennzeit in der deutschen Traberpopulation. Züchtungskunde 49: 185192.

Klemetsdal, G. 1989. Norwegian trotter breeding and estimation of breeding values. In: Langlois, B. (ed.). State of breeding evaluation in trotters. EAAP Publications No 42, Wageningen Pers, Wageningen. p. 95-105.

Leroy, P.L., Kafidi, N. \& Bassleer, E. 1989. Estimation of breeding values of Belgian trotters using an animal model. In: Langlois, B. (ed.). State of breeding evaluation in trotters. EAAP Publications No 42, Wageningen Pers, Wageningen. p. 3-17.

Minkema, D. 1989. Breeding value estimation of trotters in Netherlands. In: Langlois, B. (ed.). State of breeding evaluation in trotters. EAAP Publications No 42, Wageningen Pers, Wageningen. p. 82-94.

Ojala, M. 1982. Some parameters estimated from a restricted set of race records in trotters. Acta Agriculturae Scandinavica 32: 215-223.

- \& Hellman, T. 1987. Effects of year, sex, age and breed on annually summarized race records for trotters in Finland. Acta Agriculturae Scandinavica 37: 463-468.

- \& Van Vleck, L.D. 1981. Measures of racetrack per- formance with regard to breeding evaluation of trotters. Journal of Animal Science 53: 611-619.

Physick-Sheard, P.W. 1986. Career profile of the Canadian Standardbred II. Influence of age, gait and sex upon number of races, money won and race times. Canadian Journal of Veterinary Research 50: 457470.

Pösö, J. 1993. Ravikilpailumenestystä kuvaavien mittojen periytyvyys ja niiden väliset yhteydet kilpailu-uran eri vaiheissa. M.Sc. Thesis. University of Helsinki, Department of Animal Science Publications No 3, Helsinki. 61 p.

- \& Ojala, M. 1997. Estimates of genetic parameters of trotting performance traits for repeated annual records. Agricultural and Food Science in Finland 6: 11-18.

Rönningen, K. 1975. Genetic and environmental factors for traits in the North-Swedish trotter. Zeitschrift für Tierzüchtung und Züchtungsbiologie 92: 164-175.

Tavernier, A. 1989. Breeding evaluation of French trotters according to their race earnings. 2. Prospects. In: Langlois, B. (ed.). State of breeding evaluation in trotters. EAAP Publications No 42, Wageningen Pers, Wageningen. p. 41-54.

\section{SELOSTUS}

\section{Ravikilpailumenestysmittojen periytymisasteet ja toistumiskertoimet kilpailukohtaisten tulosten perusteella}

\author{
Terhi Thuneberg-Selonen, Jukka Pösö, Esa Mäntysaari ja Matti Ojala \\ Maatalouden tutkimuskeskus ja Helsingin yliopisto
}

Vuonna 1996 käynnistyneen projektin tarkoituksena oli kehittää eläinmalli-BLUP -menetelmään perustuva ravihevosten jalostusarvostelusysteemi. Lähtökohtana oli kilpailukohtaisten tulosten tarjoama mahdollisuus määritellä entistä tarkempi tuloksia kuvaava tilastollinen malli, jonka avulla hevosia pystytään vertaamaan kilpailukohtaisesti. Ensisijaisena vertailuryhmänä olisivat kaikki samaan lähtöön osallistuvat hevoset, eli ne, joita vastaan hevonen kilpailee.

Tutkimuksessa määritettiin tilastollinen malli ja perinnölliset tunnusluvut kilpailukohtaisille tuloksille. Tarkastelun kohteena oli kolme ravikilpailumenestystä mittaavaa tekijää: kokonaisaika, sijoitus ja voittosumma. Analyyseissä olivat mukana tulokset Vermon keskusradalta ja Etelä-Suomen maakuntaradoilta. Suomenhevosten osalta aineisto (SH) käsitti vuo- det 1991-1995 ja sisälsi 81643 kilpailukohtaista tulosta 4808 eläimeltä. Lämminveristen hevosten aineisto (LV) jouduttiin laskentateknisistä syistä rajaamaan vuosiin 1993-1995, käsittäen 74855 tulosta 5869 eläimeltä. Sukulaisuudet otettiin huomioon kolmen sukupolven ajalta.

Käyttökelpoisen tilastollisen mallin todettiin sisältävän seuraavat kiinteät ympäristötekijät: sukupuoli, ikä, ohjastaja, lähetystapa-lähtörata ja lähtö. Ohjastajan vaikutus oletettiin kiinteäksi, ajokokemuksen mukaan luokitelluksi tekijäksi. Ohjastajaa testattiin myös satunnaistekijänä; tällöin mallin avulla oli kuitenkin vaikea erottaa ohjastajan ja pysyvän ympäristötekijän vaikutukset toisistaan. Lähetystapa ja lähtörata yhdistettiin yhdeksi tekijäksi, koska auto- ja tasoituslähdöittäin lähtöratojen ratkaisut olivat erilai- 
Vol. 8 (1999): 353-363.

set. Kiinteä lähtötekijä, joka koostui päivämäärästä, raviradasta ja lähdön numerosta, johtaa eläinten vertailuun kunkin lähdön sisällä, jolloin erillistä juostavan matkan pituutta kuvaavaa tekijää ei tarvittu. Lisäksi tilastollinen malli sisälsi eläimen jalostusarvoa kuvaavan termin sekä eläimen ei-perinnöllistä vaikutusta kuvaavan tekijän. Tämä ns. pysyvä ympäristötekijä jaettiin kahteen osaan: ensimmäinen kuvaa kilpailutulosten toistuvuutta hevosen koko uran ajalta, toinen kunkin kilpailuvuoden sisällä. Kun pysyvä ympäristötekijä jaettiin kahteen eri osaan, mallin selitysaste parani.

Molemmilla roduilla kokonaisajan $\left(\mathrm{SH} \mathrm{h}^{2}=0,23\right.$ $\left.\mathrm{LV} \mathrm{h}{ }^{2}=0,28\right)$, sijoituksen $\left(\mathrm{SH}\right.$ ja $\left.L V h^{2}=0,12\right)$ ja voit- tosumman $\left(\mathrm{SH} \mathrm{h}^{2}=0,05 \mathrm{ja} \mathrm{LV} \mathrm{h}{ }^{2}=0,09\right)$ periytymisasteet vaihtelivat alhaisesta kohtalaiseen. Kokonaisaikaa voidaan pitää monipuolisimpana kilpailumenestyksen mittana, koska se kertoo sekä hevosten järjestyksen että niiden väliset erot. Sijoitus kertoo ainoastaan hevosten järjestyksen, kun taas voittosumma asettaa samanarvoisiksi kaikki ne hevoset, jotka eivät ole saaneet rahapalkintoja. Toisaalta hylättyjen ja keskeyttäneiden hevosten huomioiminen jalostusarvostelussa on tärkeää, sillä niiden huomiotta jättäminen vääristää jalostusarvoja. Eräs ratkaisuvaihtoehto olisi kokonaisajan ja voittosumman käyttäminen samanaikaisesti jalostusarvostelussa. 
AGRICULTURAL AND FOOD SCIENCE IN FINLAND 